\title{
High Order Thinking Skills (HOTS) Students in Solving Mathematics Problem of Group Theory Based on Gender
}

\author{
Suesthi Rahayuningsih ${ }^{1}$, Rani Jayanti ${ }^{2}$ \\ ${ }^{1,2}$ Universitas Islam Majapahit, Mojokerto \\ ${ }^{1}$ Correspondence Adress; esthiachmad@gmail.com
}

\begin{abstract}
The purpose of this research were to 1) describe the High Order Thinking Skill (HOTS) of male students in solving mathematics problem of group theory, and 2) describe the High Order Thinking Skill (HOTS) of female students in solving mathematics problem of group theory. This research was a descriptive research with a qualitative approach. Data collection was done by taskbased interviews. The interview revealed High Order Thinking Skills (HOTS) based on indicators analyzing, evaluating and creating. The data in this research was in the form of interviews and tests of group problems. To check the validity of the data triangulation was done. The triangulation done was time triangulation. This research involved 19 students, which consisted of 3 male students and 16 female students. The results of the research showed that the thinking ability of male students in solving group problems at the analysis stage was $66.67 \%$, at the evaluation stage of $33.33 \%$ and at the creation stage of $0 \%$. While the thinking ability of female students in solving group problems at the analysis stage was $62.5 \%$, at the evaluation stage at $43.75 \%$ and at the creation stage of $0 \%$. This showed that mastery of HOTS in the analysis aspect, male students were better than female students while in the evaluation stage female students were better than male students. And at the creation stage, male students got the same score as female students. Overall it showed that the aspect of analyzing that has the highest value compared to evaluating and creating because analyzing was the lowest level of ability of HOTS.
\end{abstract}

Keywords: High Order Thinking Skills; Group Problem; Gender.

\section{INTRODUCTION}

Group theory is a course that discusses the types, nature and relationships between groups in solving related problems. As a compulsory course, students are expected to master the group theory material provided. But the learning outcomes of students during the four semesters during the authors taught the group theory courses are still low. The results of interviews conducted by the author to students, there are $75 \%$ of students think that the difficulty factor is caused by abstract group theory material. This is in line with (Fortunatadewi, 2012) because of its abstract nature, Abstract Algebra is difficult to learn by students so it is less desirable. (Yuniati, 2013) added that algebraic structure is a course that contains abstract concepts, so students often have difficulty in learning it. And based on the results of research (Idris, 2009) states that many students in tertiary institutions have weak mathematical and algebraic concepts. This shows that learning group theory is a problem for students.

Problems are challenging conditions that the way to solve them is not immediately visible to students. According to (Ozturk \& Guven, 2016) argues that in solving problems, complex rules or high-level rules are needed to be achieved after mastering defined rules and concepts. Based on the results of the PISA survey/(Program for International Student Assessment) conducted by (OECD)/Organization for Economic Cooperation and Development in the last eight years and (TIMSS) Trends International Mathematics and Science Study organized by the International Association for the Evaluation (IEA) of Education Achievement in 2015 shows 
that Indonesian students are still relatively weak in problem solving activities that require students to be able to use High Order Thinking Skills (HOTS) (Arifin \& Ratu, 2018). So students are said to be able to solve a problem if the student is able to study a problem and be able to use his knowledge into new situations. This ability is usually known as High Order Thingking Skills (HOTS).

High Order Thinking Skills (HOTS) is a process of thinking of students in a higher cognitive level that is developed from various cognitive concepts and methods and learning taxonomies such as the method of problem solving, bloom taxonomy, and the taxonomy of learning, teaching, and assessment (Saputra, 2016). According to (Sastrawati, Rusdi, \& Syamsurizal, 2011) higher level thinking is a process that involves mental operations such as classification, induction, deduction, and reasoning. In the high-level thinking process often faced with a lot of uncertainty and also demands a variety of applications that sometimes conflict with the criteria that have been found in the evaluation process. But more important in this thought process is the construction and demands of understanding and meaning whose structure is found by irregular students. (Heong et al., 2011) High Order Thinking Skills (HOTS) are defined as the widespread use of the mind to find new challenges. This ability to think at a higher level requires someone to apply new information or prior knowledge and manipulate information to reach possible answers in new situations. High Order Thinking Skills (HOTS) will occur when someone associates new information with information already stored in his memory and relates it and / or rearranges and develops the information to achieve a goal or find a solution to a difficult situation to solve.

Based on (Krathwohl, 2002) in A Review of Bloom's Taxonomy: an overview - theory Into Practice states that indicators to measure the ability to think at a higher level include analyze, which is namely analyzing incoming information and dividing or structuring information into sections smaller to recognize patterns or relationships, which include analyzing incoming information and dividing or structuring information into smaller parts to recognize patterns or relationships, identify and distinguish the causes and effects of a complex scenario and identify / formulate questions . Evaluate, which is making decisions based on the criteria of checking and criticizing, which includes providing an assessment of ideas, solutions and methodologies using suitable criteria or existing standards to ensure the value of effectiveness or benefits, making hypotheses, criticizing and testing and accepting or reject a statement based on predetermined criteria. And create, which is to put elements together to form a coherent whole or produce results, such as compiling, planning and producing, which includes making generalizations of ideas or ways of looking at things, designing ways to solve problems and organizing elements or parts into new structures like never before.

And the factors that influence human High Order Thinking Skills (HOTS) are gender differences. Based on the results of research (Rahayuningsih \& Feriyanto, 2018) about the thought process of male and female students in solving group problems shows a significant difference, where the thought process in mathematics cannot be separated from High Order Thinking Skills (HOTS). And supported also by the results of research (AUSSE, 2010) and (Ariffin, Daud, Ariffin, Rashid, \& Badib, 2011) at the stage of thinking at a higher level, men 
are better than women. This shows that mathematics cannot be separated from High Order Thinking Skills (HOTS) as well as gender differences which are indicated by the diversity of gender roles in mathematics learning. So the authors are interested in conducting research with the theme of High Order Thinking Skill (HOTS) analysis of students in solving group problems in terms of gender. The purpose of this research are to 1) describe the High Order Thinking Skill (HOTS) of male students in solving mathematics problem of group theory, and 2) describe the High Order Thinking Skill (HOTS) of female students in solving mathematics problem of group theory.

\section{THE RESEARCH METHODS}

Explorative research with a qualitative approach used in this research. Explorative research is research that aims to explore broadly the causes or things that influence the occurrence of something. The researcher's assumption uses exploratory research in this research because the researcher wants to explore broadly about students' high order thinking skills (HOTS) in solving group problems in terms of gender. And according to (Moleong, 2010) a qualitative method is a research procedure that produces descriptive data in the form of written or oral words from people and observable behavior. According to them this approach is directed at the background and the whole individual. The basis of researchers using a qualitative approach is that researchers want to know in depth about the ability of students to solve High Order Thinking Skills (HOTS) questions on group material.

The instruments in this research were grouped into main instruments and supporting instruments. The main instruments are the researcher himself and the supporting instruments in this research are the problem solving test (TPM) and interview guidelines. The questions were given to 19 6th semester students of the mathematics education research program at Majapahit Islamic University, Mojokerto. Then one male student and one female student in the same and communicative category were chosen as subjects.

Data collection in this research was carried out using the task-based interview method conducted by the researcher himself who was the main instrument to the subject. Subjects were given a problem solving test (TPM) and an interview was conducted. And triangulation was carried out to check the validity of the data in this research. Triangulation used in this research is time triangulation. Data analysis was performed with indicators of High Order Thinking Skills (HOTS) consisting of levels of analyzing, evaluating, and creating.

\section{THE RESULTS OF THE RESEARCH AND THE DISCUSSION}

Based on the results of the HOTS test analysis given to students of the Majapahit Islamic University Mathematics Education Study Program, from 19 students consisting of 3 male students and 16 female students in the aspects of analysis, evaluation and creating the ability of male students to think in solving group problems in the analysis phase was $66.67 \%$, at the evaluation stage it was $33.33 \%$ and at the creation stage it was $0 \%$. While the thinking ability of female students in solving group problems at the analysis stage was $62.5 \%$, at the evaluation stage at $43.75 \%$ and at the creating stage at $0 \%$ and shown in Figure 1 below. 


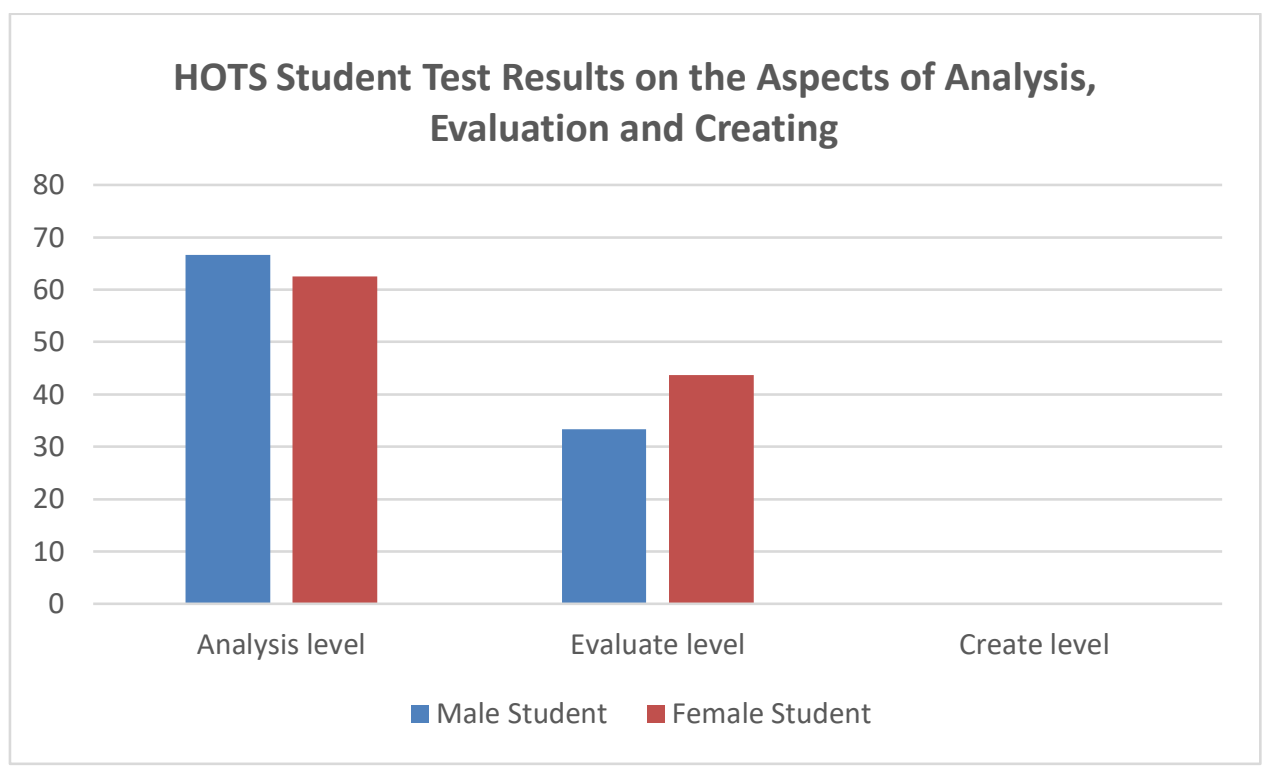

Figure 1. HOTS Test Results for Male and Female Students

Based on figure 1, it shows that mastery of HOTS aspects in solving problems of groups of male and female students at the analysis stage is better than the evaluation and creating stages. And, it shows that in the analysis aspect, male students are better than female students, while in the evaluation stage female students are better than male students. At the stage of creating, male students get the same score as female students. Overall it shows that the aspect of analyzing that has the highest value compared to evaluating and creating, because analyzing is the lowest ability level of HOTS. This is in line (Prasetyani, Hartono, \& Susanti, 2016) states that the aspect of analyzing which has the highest value compared to evaluating and creating because analyzing is the lowest level of ability of high-level thinking ability so that more students succeed on the indicator compared to the indicator of level thinking other height.

Based on an analysis of interview-based test results, obtained by High Order Thinking Skills (HOTS) male and female students in solving group problems as follows:

Male students in analyzing the problem, first read the questions given slowly once, then read silently four times and explain the reason for reading slowly once to get the information contained in the questions. The subject can recognize information on the problem from what is known to the problem and the subject divides the information contained in the problem into groups $G$ and $H$. Subject distinguishes the information that exists on the problem given to group $G$ and group $H$. The subject can formulate the questions in the given problem are asked to investigate whether $H$ subgroups of $G$ but the subject cannot recognize the patterns and relationships between the information contained in the problem so that it is not appropriate in solving the given problem, the subject shows the closed nature of $H$ by assuming that $a$ is a generator which is a smallest integer such that member $H$ is a positive number. And at the end of the answer the subject concluded correctly, namely $H$ subgroups from $G$. In the evaluation stage, male students made a solution to solve the problem given, namely proving that each cyclic group was an abelian group. The subject arranges the idea and the solution step by 
assuming $(G, *)$ is a cyclic group with a generator, then proves that $g_{1} \cdot g_{2}=g_{2} . g_{1}$ for each $g_{1}$ and $g_{2}$ element $G$. The subject makes a hypothesis to resolve the given problem namely cyclic group $G$ an abelian or commutative group. In testing the hypothesis that has been made, the subject takes any number in $G$, namely $g_{1}$ and $g_{2}$. The subject in testing the hypotheses that were made, is not quite right in understanding the binary operations that are given. The subject considers the binary operations given to $G$ to be the sum then is shown to apply commutative properties. But at the end of the answer, the subject accepts the hypothesis that has been made namely Group $G$ is the abelian group, then the cyclic group is the abelian group. In the creating stage, the subject generalizes from a given problem, namely $G$ is a group. The subject devised a way which is to show that the $G$ group by having its own subgroup was then shown to be a cyclic subgroup. The subject carried out the settlement in accordance with the design of the solution made and the subject organized the existing information on the problem provided into a new structure, namely a cyclic subgroup, but the steps taken were not appropriate. The subject can form a new structure that is only a cyclic subgroup, although with a step that is not quite right. The subject can only make one new structure, because that is considered the easiest to find and the subject is not able to make a new structure in accordance with the right steps of the problem given because of how confused how to make it.

While HOTS female students, at the stage of analyzing the subject first read the questions given sequentially in their hearts three times to obtain information in the questions. Subjects can recognize information on the problem from known things, namely $G$ group with binary operations * and $H$. Subjects distinguish information that exists in the problem, among others, $G$ group and $H$ are an set with n elements of integer set, then formed in $H=\left\{\ldots, \frac{1}{a^{2}}, \frac{1}{a}, 1, a, a^{2}\right.$, ... $\}$. The subject can formulate questions on the problem that is to show that $\mathrm{H}$ is a subgroup of $G$. Subject cannot recognize patterns and relationships between the information in the problem so that it is less precise in solving the given problem, the subject resolves by proving $H$ is a subgroup using group conditions namely is closed, is associative, has an identity element and has an inverse. But at the end of the answer the subject concludes with exactly $\mathrm{H}$ subgroups from $G$. In the evaluation stage, female students make solutions according to the problem given that is to prove each cyclic group is an abelian group. The subject arranges the idea and the solution step with $A$ is the cyclic group, then the subject proves that the cyclic group is commutative. This shows that the hypothesis made by the subject is a commutative cyclic group. Subjects tested hypotheses that were made by showing the associative nature then continued the commutative nature. In showing the associative nature, the subject takes any $a$, $b, c$ element $G$. And continues to show the commutative nature by taking any $a, b$ element $G$. The steps taken by this subject in testing the hypothesis, are less precise but at the end of the answer, the subject accepts the hypothesis that has been made that each cyclic group is a commutative group because it is commutative. In the creating phase, the subject generalizes from the given problem, namely $G$ is a cyclic group by proving in advance that $G$ is a cyclic group with the group conditions step which is closed, associative, has an identity element and has an inverse nature. This step is not appropriate because it does not pay attention to the requirements of the cyclic group. Then the subject devised a way, if $G$ is a cyclic group, then a 
subgroup of $G$ is a cyclic subgroup. The subject carried out the settlement in accordance with the draft settlement made and the subject organized the existing information on the given problem into a new structure, namely a cyclic subgroup, with the first step of making three subsets of $G$ namely $\{1\},\{1,-1\}$ and $\{1,-1, i,-i\}$. The three subsets are proven to be a subgroup of $G$, using group conditions that are closed, associative, have an identity element and have an inverse without regard to the specific requirements of a subgroup. But at the end of the answer, the subject mentions three new structures namely three cyclic subgroups $A, B$ and $C$.

From the above analysis, at the analysis stage to get information on the questions given, the two subjects read the questions first, but the female subjects were more coherent and detailed in reading them than the male subjects, according to (Kuntjara, 2003) women tended to do more review compared to men in reading, so that it is more detailed and follows the story line. And both subjects can recognize information about the problem from what is known in the problem and the subject divides the information there. In line with (Carvalho, 2017) states that men and women receive information by translating known elements. But in dividing up the information there is different between male subjects and female subjects. And the two subjects cannot recognize patterns and relationships between information that the subject has divided up, so in solving the problem it is not quite right. This shows that the knowledge possessed influences the steps to be taken, this is in accordance with (Amir, 2015) the knowledge possessed by a person (individual) beforehand and the purpose of how he determines what is relevant. Although the final results of the two subjects concluded that the H subgroup $G$. In the evaluation stage, the male subjects formulate ideas by proving that each cyclic group is an abelian group, whereas the female subject let A be a cyclic group. This shows that the male subject in compiling ideas is more precise than the female subject Likewise in making hypotheses and testing the hypotheses made, male subjects are more precise than female subjects. This is in accordance with the results of the research (Eldy \& Sulaiman, 2013) which states that at a high level of thinking, men are better than women. In the creation stage, the two subjects cannot create new structures with the right steps even though the subject of discovery at the end of the answer mentions three new structures namely $A, B$ and $C$ and male subjects mention one cyclic subgroup. This is because, at the creation stage is the highest stage at the HOTS level so that the subject has difficulty in achieving indicators at that stage, because it requires the ability to combine existing information in the problem to form a new structure. This is in line with (Brookhart, 2010) states that the ability of creation/ creation is the ability to combine elements to form a new and unique structure, design ways, and find answers to more than one (multiple solutions).

\section{CONCLUSION AND SUGGESTION}

Based on the research results obtained by the difference in High Order Thinking Skills (HOTS) in solving group problems between male and female students. Mastery of HOTS aspects in solving group problems in the analysis aspect, male students are better than female students, while in the evaluation stage female students are better than male students. And at the creation stage, male students get the same score as female students. Overall it shows that the 
aspect of analyzing that has the highest value compared to evaluating and creating because analyzing is the lowest level of ability of HOTS.

Based on the conclusions, gender differences affect students' High Order Thinking Skills (HOTS) in solving group problems, so lecturers or prospective lecturers are expected to pay attention to these conditions in classroom learning activities in group theory material in order to provide positive learning outcomes, and of course the results of this research can be used as one of the information materials to make a broader research about HOTS students in solving group problems with different characteristics.

\section{REFERENCES}

Amir, A. (2015). Pemahaman Konsep dan Pemecahan Masalah dalam Pembelajaran Matematika. Logaritma: Jurnal Ilmu-Ilmu Kependidikan Dan Sains, 3(1), 13-28.

Ariffin, S. R., Daud, F., Ariffin, R., Rashid, N. A., \& Badib, A. (2011). Profile of Creativity and Innovation Among Higher Learning. Institution Students in Malaysia. World Applied Sciences Journal 15 (Innovation and Pedagogy for Lifelong Learning), 36-41.

Arifin, \& Ratu, N. (2018). Profil Higher Order Thinking Skill Siswa dalam Menyelesaikan Masalah Bangun Datar Segi Empat. Maju, 5(2), 52-63.

AUSSE. (2010). Student Outcomes Briefing Australian National University. Australian National University.

Brookhart, S. M. (2010). How to Assess Higher Order Thinking Skills in Your Classroom. Alexandria: ASCD.

Carvalho, S. F. L. De. (2017). Analisis Kemampuan Siswa dalam Pemecahan Masalah Berbentuk Soal Cerita pada Pembelajaran Matematika Ditiinjau dari segi Gender pada Materi Segiempat Siswa Kelas VII F SMP Negeri 1 Seyegan. Universitas Sanata Dharma Yogyakarta.

Eldy, E. F., \& Sulaiman, F. (2013). The Role of PBL in Improving Physics Students' Creative Thinking and Its Imprint on Gender. International Journal of Education and Research, 1(6), 1-10.

Fortunatadewi, F. (2012). Pengembangan Program Aplikasi Pengujian Struktur Aljabar(Ring dan turunannya, Field, dan Ideal). Universitas Bina Nusantara. Retrieved from http://library.binus.ac.id/

Heong, Y. M., Othman, W. D., Md Yunos, J., Kiong, T. T., Hassan, R., \& Mohamad, M. M. (2011). The Level Of Marzano Higher Order Thinking Skills Among Technical Education Student. International Journal Of Social And Humanity, 1(2), 121-125.

Idris, N. (2009). Enhancing Students' Understanding in Calculus Trough Writing. International Electronic Journal of Mathematics Education, 4(1), 36-55.

Krathwohl, D. R. (2002). A revision of Bloom's taxonomy: An overview. Theory into Practice, 41(4), 212-218. 
Kuntjara, E. (2003). Gender, Bahasa, dan Kekuasaan. Jakarta: PT BPK Gunung Mulia Jakarta dan UK Petra Surabaya.

Moleong, L. (2010). Metodologi Penelitian Kualitatif (Revisi). Bandung: PT Remaja Rosda Karya.

Ozturk, T., \& Guven, B. (2016). Evaluating Students' Beliefs in Problem Solving Process: A Case Study. Eurasia Journal of Mathematics, Science \& Technology Education, 12(2), 411-429.

Prasetyani, E., Hartono, Y., \& Susanti, E. (2016). Kemampuan Berpikir Tingkat Tinggi Peserta didik Kelas XI dalam Pembelajaran Trigonometri Berbasis Masalah di SMA Negeri 18 Palembang. Jurnal Gantang Pendidikan Matematika FKIPUMRAH, 1(1), 31-40.

Rahayuningsih, S., \& Feriyanto. (2018). Proses Berpikir Mahasiswa dalam Memecahkan Masalah Grup Ditinjau dari Gender. Jurnal Pendidikan:Teori, Penelitian, Dan Pengembangan, 3(12), 1672-1681.

Saputra, H. (2016). Pengembangan Mutu Pendidikan Menuju Era Global: Penguatan Mutu Pembelajaran dengan Penerapan HOTS (High Order Thinking Skills). Bandung: SMILE's Publishing.

Sastrawati, E., Rusdi, M., \& Syamsurizal. (2011). Problem-Based Learning, Strategi Metakognisi, dan Ketrampilan Berpikir Tingkat Tinggi Siswa. Tekno-Pedagogi, 1(2), 114.

Yuniati, S. (2013). Peta Konsep (Mind Mapping) dalam pembelajaran Struktur Aljabar. Gamatika: Jurnal Gagasan Matematika Dan Informatika, 3(2), 129-139. 